\title{
Pelatihan Dan Pendampingan Daring Dalam Rangka Peningkatan Literasi Keuangan Praktek Mandiri Bidan Di Kecamatan Sukasada
}

\author{
Luh Gede Kusuma Dewi ${ }^{1}$, Luh Ari Arini ${ }^{2}$, Putu Riesty Masdiantini ${ }^{1}$ \\ ${ }^{1}$ Dosen Program Studi S1 Akuntansi Universitas Pendidikan Ganesha \\ ${ }^{2}$ Dosen Program Studi D3 Kebidanan Universitas Pendidikan Ganesha. \\ Email: dewi.kusuma.dewi@undiksha.ac.id
}

\begin{abstract}
Abstrak - Profesi Bidan diharapkan memiliki jiwa kewirausahaan, oleh karena itu Praktek Mandiri Bidan (PMB) merupakan salah satu usaha mikro kecil dan menengah (UMKM) yang berjalan dalam menghasilkan laba untung menutupi kegiatan operasional dan pengembangan karirnya. Setiap usaha tidak terlepas dari kegiatan pencatatan keuangan. Hal ini sebagai kontrol dalam kemajuan usaha yang dijalankan. Berdasarkan hasil wawancara dan observasi, masih banyak PMB yang tidak melakukan pencatatan keuangan dengan baik sesuai SAK EMKM. Oleh karena itu dampak yang telah dirasakan oleh mereka adalah ketidaktahuan dari jasa pelayanan yang telah dilakukan menghasilkan laba atau tidak. Berdasarkan keadaan tersebut maka diperlukan adanya pelatihan dan pendampingan guna meningkatkan literasi keuangan PMB. Kegiatan pelatihan dan pendampingan secara daring disambut dengan antusiasme para Bidan yang memiliki usaha Praktek Mandiri Bidan di Kecamatan Sukasada. Materi yang telah dipaparkan dalam kegiatan pelatihan adalah pengetahuan mengenai kebidanan di era revolusi industri 4.0; Pajak Penghasilan Bagi Bidan; dan Peningkatan Literasi Keuangan Bidan Melalui Aplikasi Keuangan LAMIKRO. Materi yang diberikan saat pendampingan adalah Penggunaan Aplikasi LAMIKRO; Pengenalan Transaksi Keuangan; Kasus Keuangan Praktek Mandiri Bidan I; dan Kasus Keuangan Praktek Mandiri Bidan II. Berdasarkan hasil dari pre-test dan post-test menunjukkan adanya peningkatan pengetahuan para Bidan setelah melaksanakan pelatihan. Dan berdasarkan kuesioner yang disebar, para Bidan yang mengikuti kegiatan pelatihan dan pendampingan merasakan manfaat dari kegiatan ini serta menginginkan pelatihan yang lebih intensif di kesempatan berikutnya. Para Bidan pun mengusulkan adanya pengembangan aplikasi transaksi keuangan yang lebih mendetail yang dikhususkan untuk usaha jasa kesehatan PMB.
\end{abstract}

Kata kunci : Literasi Keuangan, Praktek Mandiri Bidan, Lamikro

\begin{abstract}
The midwives profession are expected to have an entrepreneurial spirit, therefore the Midwives Independent Services is one of the micro, small and medium enterprises (MSMEs) that runs in generating profits to cover operational activities and career development. Every business cannot be separated from financial recording activities. This is a control in the progress of the business being carried out. Based on the results of interviews and observations, there are still many of them that do not carry out financial records properly according to SAK EMKM. Therefore, the impact that has been felt by them is ignorance of the services that have been carried out to generate profits or not. Based on these circumstances, it is necessary to have training and mentoring to improve The midwives financial literacy. The training and mentoring online activities were greeted with enthusiasm from the midwives who have a Midwives Independent Practice business in Sukasada District. The topic presented in the training activities was knowledge about midwifery in the era of the industrial revolution 4.0; Income Tax for Midwives; and Improving Midwives' Financial Literacy through the LAMIKRO Financial Application. The topic provided at mentoring sessions are the use of the LAMIKRO application; Introduction to Financial Transactions; Midwives Independent Practice Financial Case I; and Midwives Independent Practice Financial Case II. Based on the results of the pre-test and post-test, there was an increase in the knowledge of the midwives after implementing the training. And based on the questionnaire distributed, the midwives who participated in the training and mentoring activities felt the benefits of this activity and wanted more intensive training for the next opportunity. The midwives also suggested the development of a more detailed financial transaction application specifically for their health service businesses.
\end{abstract}

Keywords: Financial Literacy, Midwives Independent Services, Lamikro 


\section{PENDAHULUAN}

Dalam kode etik profesi bidan menuntut bidan memberikan kualitas pelayanan yang terbaik kapanpun dan dimanapun mereka membuka praktek mandiri. Ikatan Bidan Indonesia (IBI)[1] menyebutkan beberapa nilai-nilai yang harus dijunjung oleh Bidan Delima, salah satunya adalah kewirausahaan. IBI menegaskan bahwa Bidan delima haruslah menjunjung dan menerapkan nilai kewirausahaan sebagai upaya terus maju dan tumbuh lebih baik. Hal ini menunjukkan Profesi Bidan merupakan salah satu usaha mikro kecil dan menengah (UMKM) yang berjalan dalam menghasilkan laba untung menutupi kegiatan operasional dan lainnya. Dalam menjalankan suatu usaha tentu tidak terlepas dari kegiatan pencatatan keuangan. Hal ini sebagai kontrol dalam kemajuan usaha yang dijalankan.

Literasi keuangan yang rendah akan berdampak pada pembuatan keputusan dalam kehidupan sehari-hari. Ningtyas[2] dalam penelitiannya menyebutkan bahwa pembuatan keputusan yang salah akan mengakibatkan pengelolaan keuangan yang buruk serta tidak efektif, sehingga hal ini dapat mengakibatkan orang pribadi atau sebuah unit usaha rentan akan krisis keuangan dan berpotensi mengalami kerugian. Laporan keuangan sederhana mencerminkan kemajuan atau kemunduran usaha yang dijalankan dalam periode tertentu [3]. Berdasarkan hasil wawancara dan observasi yang dilakukan di lapangan, masih banyak bidan yang memiliki praktik mandiri tidak melakukan pencatatan keuangan yang sesuai dengan SAK EMKM. Oleh karena itu dampak yang telah dirasakan oleh mereka adalah ketidaktahuan dari pelayanan kebidanan dan kesehatan yang telah dilakukan tersebut telah menghasilkan laba atau tidak, dan seberapa banyak laba yang diperoleh. Beberapa bidan menyebutkan bahwa mereka harus membeli obat-obatan dan bahan habis pakai menggunakan uang pribadinya disamping mendapat subsidi dari pemerintah daerah. Hal ini disebutkan terjadi berkali kali karena mereka tidak merasakan adanya hasil sisa usaha atau laba yang bisa digunakan dalam membeli obat-obatan yang dibutuhkan tersebut. Beberapa bidan tidak merasa terbebani dengan hal ini, karena mereka mempunyai sudut pandang "ngayah" atau menolong dengan ikhlas tanpa timbal balik. Disisi lain, bila seorang bidan secara terus menerus tidak mengontrol keuangan dalam usahanya, maka akan membawa dampak buruk bagi keuangan pribadinya dan kelanjutan usahanya. Mengingat praktek mandiri bidan mengedepankan kualitas pelayanan dengan memberikan pelayanan secara prima kepada siapapun tanpa memandang status ekonomi pasien. Keadaan ini menjadi dilema, karena ditakutkan jika keuangan usaha yang tidak terkontrol dapat mempengaruhi kualitas pelayanan,misalkan saja memberikan obat dengan kualitas rendah kepada pasien karena obat tersebut berharga murah. Data yang diperoleh dari IBI Kabupaten Buleleng Tahun 2018, diketahui terdapat anggota bidan mencapai 700 orang, namun yang mampu mendapatkan pengakuan sebagai Bidan Delima baru sekitar 62 orang. Pengakuan sebagai Bidan Delima tentunya melalui proses seperti lulus uji kompetensi, pelayanan berkualitas dan prima, pemenuhan sarana dan prasarana sesuai standar. Akan tetapi walaupun belum menyandang predikat sebagai Bidan Delima, seorang bidan terutama yang Bidan Praktek Mandiri haruslah menjalankan prinsip kewirausahaan demi perkembangan karirnya. Berdasarkan hasil observasi dan wawancara dengan pengurus Ikatan Bidan Indonesia Kabupaten Buleleng di Tahun 2019, diketahui terdapat 10 orang praktek mandiri bidan yang berada di wilayah kerja Puskesmas Sukasada I dan Puskesmas Sukasada II. Berdasarkan hasil wawancara dan observasi masih banyak dari bidan tersebut yang tidak melakukan pencatatan dan laporan keuangan, baik secara manual maupun digital. Hal ini berimbas pada kurangnya kontrol terhadap dana pribadi yang digunakan sebagai modal usaha membeli obat untuk masyarakat yang berobat. Selain itu, para bidan ini tidak memperhitungkan biaya-biaya lain yang keluar saat memberikan layanan kesehatan.

Perkembangan zaman di era revolusi industri 4.0 menuntut setiap insan mampu berubah kearah yang positif. Kemajuan di bidang digital membawa banyak sekali manfaat bagi suatu profesi [4]. Begitu pula dengan PMB, diharapkan tidak menutup diri dari perkembangan teknologi walaupun praktek pelayanan kesehatannya berada di desa-desa. Pengaplikasian teknologi oleh bidan praktek mandiri dalam pencatatan kegiatan operasionalnya akan sangat membantu efektifitas dan efesiensi operasional jasa pelayanan kesehatan yang diberikan. Salah satu yang bisa diterapkan adalah menggunakan aplikasi pencatatan keuangan berbasis desktop dan android seperti aplikasi keuangan Lamikro. Aplikasi in akan membantu PMB dalam menyusun laporan keuangannya sebagai bagian dari UMKM.

Fenomena ini membawa tim pelaksana pengabdian pada masyarakat untuk melakukan pengabdian dikalangan PMB, dengan memberikan memberikan pengetahuan dasar melalui pelatihan mengenai keuangan PMB, dan penggunaan aplikasi keuangan Lamikro untuk dapat meningkatkan literasi keuangan dalam PMB. Menurut Jaya et al. [5], permasalahan yang sering terjadi didalam usaha PMB adalah sistem pencatatan keuangan yang tidak efektif sehingga menghambat proses pembuatan 
laporan keuangan. Permasalahan tersebut juga dialami oleh PMB yang terdapat di Kecamatan Sukasada.

Kegiatan ini dirancang untuk memberikan pemahaman konsep dasar keuangan dan mengenai pengelolaan keuangan menggunakan aplikasi keuangan Lamikro yang bertujuan untuk meningkatkan literasi keuangan PMB di Kecamatan Sukasada. Sehingga manfaat praktis yang dapat dirasakan adalah efesiensi dan efektifitas pencatatan operasional dan keuangan pada praktek mandiri bidan, sehingga dapat menunjang peningkatan kegiatan kewirausahaan yang dilaksanakan di PMB tersebut. Kegiatan pengabdian ini bertujuan untuk memberikan wawasan dan pelatihan mengenai pencatatan keuangan secara manual dan digital, dengan cara: (1) Memberikan pemahaman mengenai transaksi keuangan terkait usaha praktek mandiri bidan; dan (2) Memberikan pelatihan dan pendampingan pencatatan transaksi keuangan digital. Sehingga manfaat praktis yang dapat dirasakan oleh bidan mitra adalah efesiensi dan efektifitas pencatatan keuangan pada bidan praktek mandiri, sehingga dapat menunjang peningkatan kegiatan kewirausahaan praktek mandiri bidan.

\section{METODE PELAKSANAAN}

Pengabdian pada masyarakat akan dilaksanakan tahun 2020 secara daring mengingat kondisi di Kabupaten Buleleng masing belum kondusif akibat pandemi Covid-19. Kegiatan dihadiri oleh mitra PMB dan para asisten bidan dari Kecamatan Sukasada. Kegiatan ini diawali dari tahap pendekatan ke PMB yang berada di Sukasada melalui IBI cabang Buleleng. Penjajagan ini membahas tentang kegiatan yang akan dilaksanakan sekaligus mengundang PMB untuk mengikuti pelatihan ini. Kemudian dilanjutkan dengan penyusunan modul serta persiapan pelatihan dan pendampingan. Kegiatan dibagi menjadi 2 tahap, yang pertama pelatihan dengan pemberian materi tentang pencatatan transaksi keuangan beserta pajak profesi, dan pengetahuan mengenai profesi bidan di masa revolusi industri 4.0. Lalu tahap berikutnya dilaksanakan program pendampingan secara terprogram selama 4 kali pertemuan secara daring melalui diskusi whatsapp group. Dalam proses pendampingan ini para bidan dan asisten bidan dapat mengimplementasikan pengetahuan yang telah diterima pada saat pelatihan. Program pelatihan tanpa disinergikan dengan program pendampingan tentu tidak akan membantu optimalisasi pencapaian tujuan dari pengabdian ini. Sasaran dari kegiatan ini adalah bidan yang memiliki praktek mandiri se-Kecamatan Sukasada yaitu para bidan di wilayah kerja Puskesmas Sukasada I dan Sukasada II. Indikator yang digunakan dalam pemilihan sasaran adalah bidan yang telah memiliki usaha praktek mandiri namun belum menerapkan pencatatan keuangan dengan baik dan sesuai dalam aturan akuntansi yang berlaku.

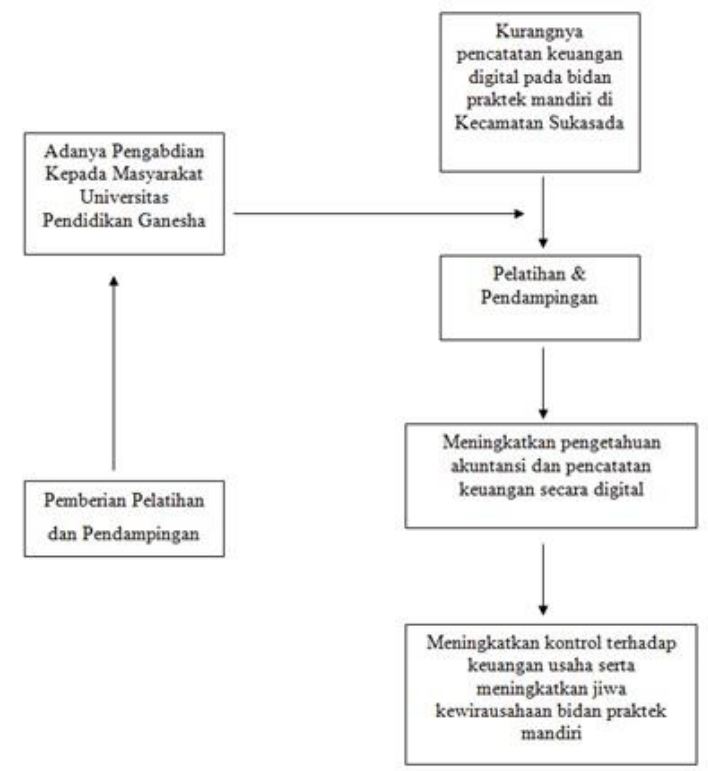

Gambar 1: Bagan Alur Kegiatan

\section{HASIL DAN PEMBAHASAN}

Kegiatan pengabdian kepada masyarakat ini dilaksanakan pada tanggal 2 sampai dengan 6 Agustus 2020 melalui pelatihan melalui webinar di Google meet dan pendampingan di Whatsapp group. Narasumber dalam kegiatan ini terdiri dari 3 (tiga) orang dosen yang merupakan tim dari pengabdian kepada masyarakat. Sebelum menyampaian materi pelatihan melalui webinar, para peserta diberikan waktu untuk mengerjakan pretest. Pretest ini berisikan daftar pertanyaan mengenai beberapa materi yang akan diberikan, meliputi pengetahuan mengenai kebidanan di era revolusi industri 4.0; Peningkatan Literasi Keuangan Bidan Melalui Aplikasi Keuangan LAMIKRO; dan Pajak Penghasilan Bagi Profesi Bidan. Materi mengenai kebidanan di era revolusi industri 4.0 dirasa perlu disampaikan untuk memberikan pandangan sejauh mana perkembangan digital Indonesia saat ini, dan kenapa profesi bidan harus mampu mengikuti perkembangan teknologi, terkait pencatatan keuangan PMB. Materi mengenai pajak profesi bidan dirasa perlu karena setiap PMB harus paham mengenai perhitungan dan pelaporan pajak, yang mana pajak merupakan sumber pendapatan negara yang dananya dari rakyat untuk kepentingan rakyat. Kegiatan dilanjutkan dengan pemaparan materi pelatihan, keseluruhan peserta mengikuti kegiatan dengan baik, walaupun terjadi beberapa kendala koneksi internet yang buruk sehingga mengakibatkan beberapa peserta harus berulang 
kali keluar-masuk Google meet. Setelah pelatihan dilanjutkan dengan post-test untuk mengetahui peningkatan pengetahuan yang didapatkan melalui pelatihan ini.

\section{Fase I: Sesi Pelatihan}

Pemateri pertama adalah Ibu Putu Riesty Masdiantini, S.E, M.Si yang memberikan materi mengenai Pajak Penghasilan Bagi Bidan: Seri PPH Profesi. Sebelum materi dimulai terlebih dahulu peserta diberikan waktu untuk mengisi formulir pre-test. Pre-test mengenai materi Perpajakan merupakan salah satu tes yang dimaksudkan untuk mengetahui tingkat pengetahuan peserta Pengabdian Masyarakat terhada pmateri yang akan disampaikan. Pada pre-test ini terdapat 4 buah soal pilihan ganda, yang mana tiap soal memiliki bobot 25 poin. Dari 4 buah soal, terdapat 2 buah soal umum terkait pengetahuan perpajakan serta 2 soal lagi khusus mengenai materi yang akan disampaikan yaitu pajak penghasilan ( $\mathrm{PPh}$ ). Terdapat 13 orang peserta yang menjawab pre test ini. Ada pun hasil dari pre test ini, nilai rata-rata yang diperoleh peserta adalah sebesar $46,1 \%$. Berdasarkan hasil pre test tersebut dapat ditarik kesimpulan bahwa tingkat pengetahuan awal peserta masih belum maksimal terkait Perpajakan. Oleh karena itu sangat penting untuk memberikan sosialisasi terkait Perpajakan untuk menambah pengetahuan peserta.

Setelah pre-test, kegiatan dilanjutkan pada pemaparan materi. Pajak Penghasilan adalah pajak atas penghasilan yg diterima wajib pajak. Khusus untuk profesi Bidan, dikategorikan Bidan dengan pekerjaan bebas, bidan dengan usaha diluar profesi dan bidan yang memperoleh penghasilan dari pemberi kerja. Untuk bidan dengan pekerjaan bebas contohnya ketika Bidan membuka klinik pribadi, menghitung sendiri pph terutang dengan menggunakan Norma Penghitungan Penghasilan Neto, sebesar 29\% (10 Ibu kota provinsi), 28\% (Ibu kota provinsi lainnya), dan 27\% (daerah lainnya). Untuk bidan dengan usaha diluar profesi, contohnya membuka apotek, dikenakan tariff 0,5\% dari omzet. Untuk bidan yang memperoleh penghasilan dari pemberi kerja, akan dipotong oleh pemberi kerja dan diberikan bukti potong. Untuk kewajiban pelaporan menyampaikan SPT Tahunan paling lambat 3 bulan setelah akhir tahun pajak. Setelah pemaparan materi, dilanjutkan dengan posttest.

Adapun hasil dari post testini, nilai ratarata yang diperoleh peserta adalah sebesar $61,5 \%$. Berdasarkan hasil post test tersebut dapat ditarik kesimpulan bahwa tingkat pengetahuan peserta masih belum maksimal terkait aspek Perpajakan. Namun jika dibandingkan hasil pre test sebelumnya, nilai rata-rata yang diperoleh peserta sudah mengalami peningkatan, jumlah peserta yang menjawab pertanyaan dengan benar juga sudah semakin meningkat. Oleh karena itu sangat penting untuk memberikan sosialisasi, pelatihan maupun pendampingan secara berkelanjutan terkait aspek Perpajakan untuk menambah pengetahuan peserta sebagai Wajib Pajak. Diharapkan dengan adanya kegiatan tersebut, peserta akan semakin memahami mengenai Perpajakan, khususnya terkait PPh untuk profesi, yaitu sebagai Bidan, baik Bidan dengan pekerjaan bebas, bidan dengan usaha diluar profesi dan bidan yang memperoleh penghasilan dari pemberi kerja.

Materi kedua disampaikan Luh Gede Kusuma Dewi, S.E., M.Si. Sebelum pemaparan materi, beberapa pertanyaan sebagai pre-test diberikan kepada peserta pelatihan. Pertanyaan pretest merupakan pertanyaan untuk mengetahui pengetahuan peserta pelatihan. Pertanyaan pertama menanyakan mengenai penggolongan aset. 69,2\% menjawab benar bahwa yang termasuk aset adalah gedung praktek. 23,1\% menjawab tarif jasa dan 7,7\% menjawab asisten bidan. Yang mana jawaban ini bukan jawaban yang tepat, dikarenakan tarif jasa termasuk kedalah komponen perhitungan pendapatan yang tercatat di laporan laba rugi. Sedangkan asisten bidan merupakan tenaga kerja yang pencatatan bebannya sebagai pengurang dari pendapatan jasa, untuk mengetahui laba usaha. Pertanyaan kedua mencari tahu bagaimana pemahaman para peserta tentang konsep hutang. Mayoritas peserta dapat menjelaskan dengan bahasanya sendiri konsep hutang. Deskripsi singkat yang mereka ungkapkan menunjukkan bahwa mereka telah cukup memahami apa itu hutang. Walaupun ada beberapa peserta yang masih belum mampu mendeskripsikan apa itu hutang. Pertanyaan ketiga menanyakan penggolongan piutang usaha. $61,5 \%$ peserta menjawab yang termasuk piutang adalah gaji asisten yang belum dibayarkan. Ini merupakan jawaban yang tidak tepat, karena gaji asisten yang belum dibayar merupakan bagian dari hutang gaji. $38,5 \%$ peserta telah menjawab dengan benar bahwa yang termasuk piutang adalah jasa yang belum dibayarkan oleh pasien. Pertanyaan terakhir mempertanyakan penggunaan aplikasi keuangan digital. Apakah para peserta pelatihan pernah menggunakan aplikasi keuangan digital dalam mencatat laporan keuangan? 100\% dari peserta pelatihan menyebutkan bahwa mereka tidak pernah menggunakan aplikasi keuangan digital dalam mencatat laporan keuangan dalam usaha jasa kesehatan PMB. Hal ini sesuai dengan informasi awal disaat tim melakukan survey terhadap mengenai pencatatan transaksi keuangan yang belum optimal. 
Kegiatan dilanjutkan dengan pemaparan materi pelatihan dengan topik Peningkatan Literasi Keuangan Bidan Melalui Aplikasi Keuangan LAMIKRO. Aplikasi Lamikro ditujukan untuk membantu penggunanya dalam menyusun laporan keuangan sesuai SAK EMKM dengan lebih praktis secara digital. Laporan Akuntansi Usaha Mikro (Lamikro) ditujukan kepada UMKM termasuk dalam usaha jasa kesehatan yang diberikan oleh Praktek Mandiri Bidan. Tahapan dalam pelatihan ini dimulai dari pengenalan mengenai pentingnya laporan keuangan bagi usaha UMKM, khususnya usaha jasa praktek mandiri bidan. Laporan keuangan bermanfaat dalam memberikan informasi posisi keuangan usaha, laba-rugi usaha, hingga membantu dalam pengajuan kredit usaha di lembaga keuangan (Bank). Lalu tahapan pelatihan berikutnya mengenai apa itu Lamikro serta fiturfitur yang terdapat dalam aplikasi lamikro. Lamikro merupakan aplikasi yang dikeluarkan oleh Kementrian Koperasi dan UKM khususnya bidang SDM. Aplikasi ini ditujukan untuk UKM Mikro di seluruh Indonesia dalam menyusun laporan keuangan, dari pembukuan harian hingga membuat neraca rugi/laba secara lebih praktis dan sederhana. Lamikro dapat membantu Praktek Mandiri Bidan, sebagai usaja di bidang jasa dalam menghadapi kesulitan menyusun laporan keuangan sesuai SAK EMKM. Aplikasi ini dapat diunduh secara online di Google playstore atau diakses melalui www.lamikro.com melalui handphone ataupun laptop.

Setelah pelatihan, peserta menjawab post test. Pertanyaan pertama menanyakan mengenai penggolongan aset. $100 \%$ dari peserta pelatihan telah mampu menjawab dengan benar bahwa yang tergolong sebagai aset adalah gedung praktek. Hal ini menunjukkan adanya kemajuan pemahaman dan pengetahuan dari peserta pelatihan mengenai komponen aset. Untuk pertanyaan kedua mengenai apa yang dimaksud dengan hutang, seluruh peserta sudah mampu mendeskripsikan apa yang dimaksud dengan hutang beserta contoh-contohnya. Pertanyaan ketiga mengenai piutang usaha, 76,9\% menjawab dengan benar bahwa yang merupakan piutang usaha adalah jasa yang belum dibayar oleh pasien. Sedangkan $23,1 \%$ masih belum tepat menjawab. Namun dibandingkan dengan soal pretest, sudah terdapat kemajuan yang positif, yang mana hanya tadinya $61,5 \%$ peserta memilih jawaban salah. Pertanyaan keempat, apakah peserta tertarik mencoba menggunakan aplikasi Lamikro dalam mencatat transaksi keuangan usaha? Atau jika ada refrensi aplikasi lain yang diinginkan? Mayoritas peserta menyatakan bahwa mereka tertarik dan bersedia mencoba menggunakan aplikasi keuangan Lamikro untuk usaha jasa PMB mereka. Dan beberapa dari mereka juga menyatakan keinginan adanya aplikasi rekam medis untuk PMB, seperti yang telah disampaikan pasa saat sesi diskusi.

Sesi terakhir, adalah materi yang dipaparkan oleh Luh Ari Arini, S.ST., M.Biomed dengan topik pengetahuan mengenai kebidanan di era revolusi industri 4.0. Sebelum pemberian materi, dilakukan pre-test. Sasaran sebagian besar mengetahui dan menjawab sesuai dengan pamahaman dan tindakan dalam pelayanan kebidanan yang telah dilakukan sehari-hari dalam praktek mandiri yakni terkait dengan tugas bidan yang profesional, wewenang bidan, pemberian pelayanan kebidanan sesuai dengan undang-undang kesehatan dan aturan menteri kesehatan. Selalu mengikuti kebijakan pemerintah dan mengupdate ilmu pengetahuan sesuai dengan peraturan menteri kesehatan terutama yang berkaitan dengan pemberian asuhan kebidanan, yang berfokus pada ibu dan anak dan peningkatan derajat kesehatan ibu dan anak serta kesehatan reproduksi wanita dan keluarga berencana. Beberapa sasaran mengetahu dengan jelas peran-perannya sebagai bidan namun ada sebagian kecil yang hanya mengetahui perannya sebagai pemberi pelayanan kebidanan, padahal bidan yang memiliki praktek mandiri tidak hanya bertindak digarda terdepan sebagai pemberi pelayanan atau asuhan kebidanan namun bisa bertindak sebagai pengelola suatu perusahaan pribadi karena didalamnya mempekerjakan orang lain baik dari junior maupun rekan sejawat untuk bekerja sama atau kolaborasi, selain itu bidan di praktek mandiri juga bertindak sebagai pemberi motivasi/ konseling kepada masyarakat atau pasiennya, sebagai penggerak dan pemberdayaan masyarakat seperti pembentukan desa siaga, posyandu dan sebagainya, sebagai pendidik atau fasilitator klinik bagi mahasiswa dari berbagai institusi kebidanan yang dijadikan sebagai lahan praktek, dan bisa sebagai peneliti yaitu dengan hasil temua-temuan kasus di masyarakat khususnya pada wanita serta pemecahannya bisa digunakan untuk bahan atau hasil riset. Setengah dari sasaran mengetahui mengenai revolusi industri 4.0 dengan pemahaman yang beragam namun intinya adalah mengenai suatu kegiatan yang dilaksanakan dengan menggabungkan digitalisasi/teknologi dan konvensional jadi sesuai dengan literasi baru yang menyangkut literasi digital/ big data, aplikasi teknologi dan humanities. Namun sebagian lagi sama sekali belum mengetahuinya. Menurut sasaran cara bidan bertahan di era revolusi industri ini adalah bekerja sesuai dengan standar oprasional prosedur baku yang dikeluarkan menkes, melakukan inovasi-inovasi terhadap pelayanan kebidanan, mengikuti pelatihan/ seminar/ workshop sesuai kompetensinya dan pelatihan IT, pemanfaatan teknologi secara terus menerus, selalu 
mengupdate ilmu dan pengetahuan yang dimiliki dalam kegiatan kegiatan informal dan nonformal.

Setelah pemaparan materi, dilanjutkan dengan post-test. Dari pertanyaan dalam bentuk pilihan ganda mengenai materi yang telah disampaikan, sebagian besar sasaran dapat menjawab dengan benar seperti pengelompokan tenaga kesehatan berdasarkan UU tenaga kesehatan, pelayanan kebidanan dan tugas dan wewenang bidan, namun beberapa sasaran saja yang tidak dapat menjawab dengan benar seperti literasi utama untuk menghadapi era revolusi industri 4.0 dan keterampilan utama yang dibutuhkan untuk menghadapi era di tahun 2020 ini. Hasil dari pertanyaan yang bersifat suatu pendapat mengenai pelaksanaan pelayanan kebidanan ditahun ini, sebagian mengatakan bahwa bidan saat ini telah memberikan asuhan kebidanan/ pelayanan yang sudah sesuai dengan tuntutan di era revolusi industri namun penguasaan teknologi belum begitu baik begitu juga yang belum melaksanakan sesuai dengan tuntutan karena disamping SDM juga berkaitan dengan beberapa daerah yang sinyalnya tidak begitu baik. Namun mayoritas bidan telah siap untuk menghadapi era revolusi industri ini dan sangat semangat untuk menambah pengetahuan terutama yang berkaitan dengan informasi teknologi serta digitalisasi. Pesan yang diberikan oleh sasaran yang berprofesi sebagai bidan kepada junior atau mahasiswa kebidanan adalah selalu meningkatkan kompetensinya tidak hanya dari segi ilmunya tetapi juga dari sektor lainnya dan penting juga dapat menguasaai teknologi, melakukan update-update ilmu kebidanan sesuai standar dan UU kesehatan yang berlaku, lebih kritis dan kreatif, membuat inovasi-inovasi dalam pelayanan kebidanan namun tetap memperhatikan sisi kemanusian, kenyamanan dan keamanan dari pasien tersebut. Para lulusan kebidanan diharapkan selain memiliki skill dan pengetahuan yang baik juga harus menjungjung etika dan norma kesopanan terlebih dalam memberikan pelayanan kepada pasien. Foto dokumentasi kegiatan pelatihan dapat dilihat dalam gambar berikut ini.

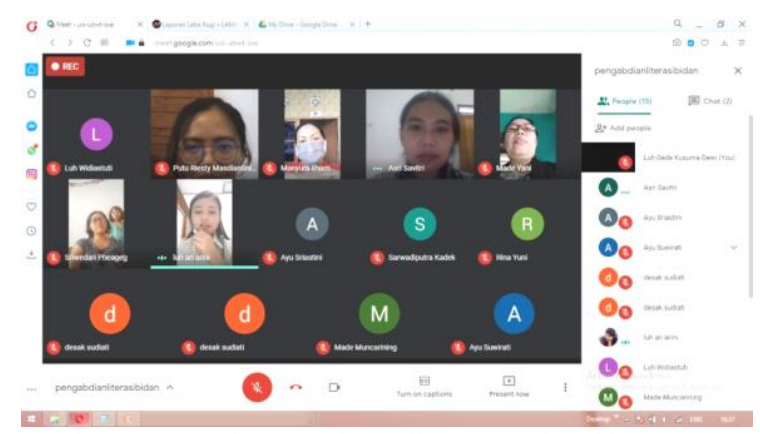

Gambar 2: Pemberian Materi Pelatihan Melalui Webinar

\section{Fase II: Sesi Pendampingan}

Pendampingan dilaksanakan setelah pelatihan dilaksanakan. Pendampingan melalui Whatsapp Group dilaksanakan selama empat hari, dengan waktu pelaksanaan yang telah disesuaikan dengan kesepakatan bidan mitra. Materi pendampingan yang diberikan setelah pelatihan adalah Penggunaan Aplikasi LAMIKRO; Pengenalan Transaksi Keuangan; Kasus Keuangan Praktek Mandiri Bidan I; Kasus Keuangan Praktek Mandiri Bidan II. Secara umum kegiatan berjalan dengan baik dan lancar. Antusiasme peserta mengikuti pendampingan disela-sela kesibukannya sebagai garda terdepan penanggulangan Covid-19 pantas diberikan pujian. Secara umum pendampingan ini cukup membantu peningkatan pengetahuan dasar mengenai keuangan usaha jasa. Akan tetapi pendampingan yang lebih intensif dirasakan perlu diterapkan pada kesempatan berikutnya.

Pelaksanaan kegiatan pengabdian kepada masyarakat berlangsung sesuai dengan yang direncanakan. Antusias peserta dalam kegiatan yang dilakukan dapat diamati melalui proses diskusi dan antusiasme peserta untuk mengikuti pelatihan ini. Praktek mandiri bidan sebagai penyedia layanan jasa kesehatan haruslah mengembangkan jiwa kewirausahaannya dan turut bersedia terus belajar dan meng-update pengetahuan dan keterampilannya di bidang teknologi. Hal ini dilakukan agar usaha jasa yang digeluti mampu bersaing di era globalisasi dewasa ini. Untuk itu kegiatan pengabdian pada masyarakat agar ditindaklanjuti dengan kegiatan serupa di tahun-tahun yang akan datang dengan memperluas kajian materi tentang pengelolaan usaha dan keuangan berbasis teknologi.

\section{Rangkuman Kondisi dan Kendala Selama Kegiatan}

Berdasarkan penjelasan mengenai kegiatan pelatihan dan pendampingan dalam pengabdian kepada masyarakat diatas, kendala-kendala yang muncul selama kegiatan dan juga solusi pemecahannya dapat dirangkum dalam tabel berikut ini.

1. Adanya pandemi covid-19 mmenjadi kendala untuk melaksanakan kegiatan dengan tatap muka secara langsung. Oleh karena itu solusi yang diambil adalah pelaksanaan kegiatan secara daring melalui webinar dengan google meet dan pendampingan daring melalui whatsapp group.

2. Ada beberapa bidan yang belum pernah menggunakan google meet. Sehingga tim memberikan instruksi tata cara penggunaan google meet melalui video tutorial. 
3. Terdapat peserta yang keluar-masuk google meet dikarenakan kendala pada jaringan internet. Tim Tetap memberikan kesempatan kepada peserta tersebut untuk bergabung, dan membagikan file materi pelatihan melalui whatssapp group.

4. Terdapat beberapa bidan yang kesulitan untuk membuat akun dan membiasakan diri dengan tampilan website Lamikro. Solusinya adalah dengan Membantu dan memandu cara membuat akun dan menjelaskan fitur-fitur Lamikro.

5. Masih terdapat beberapa bidan yang belum memahami perbedaan perlengkapan dan peralatan. Solusinya Menjelaskan perbedaan perlengkapan dan peralatan, memberikan contoh nyata, dan menjelaskan cara pencatatan melalui Lamikro.

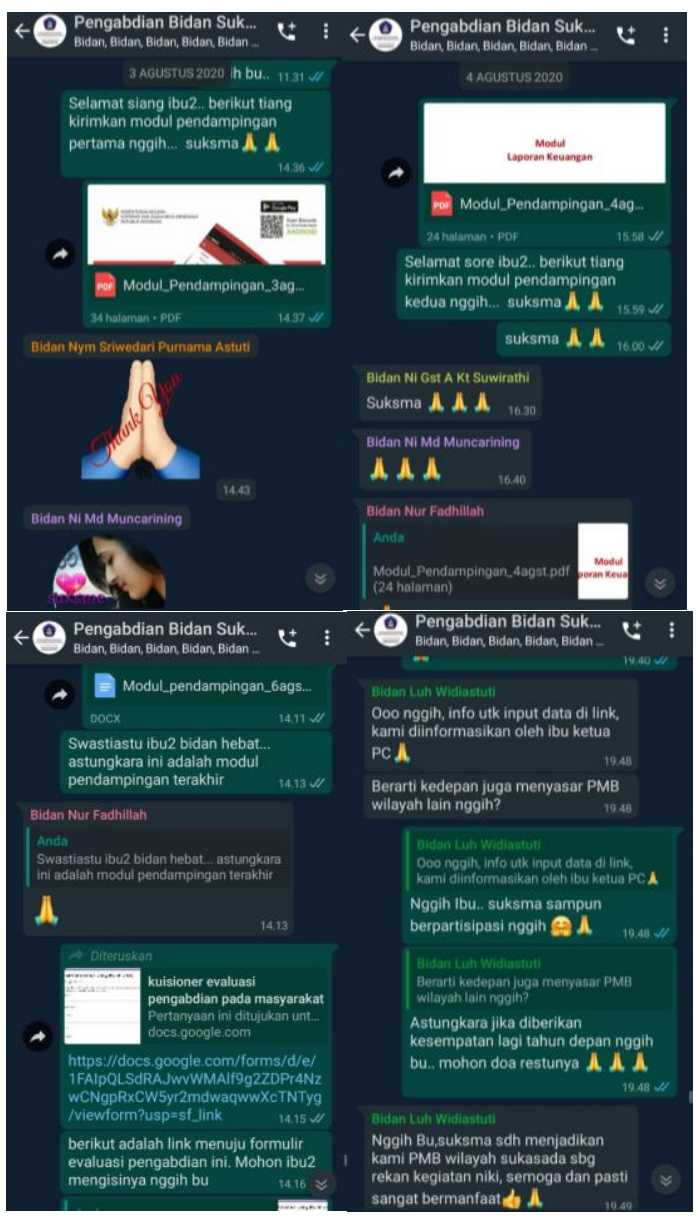

Gambar 3: Kegiatan Pendampingan Melalui Whatsapp Group

\section{KESIMPULAN DAN SARAN Kesimpulan}

Pelatihan dan Pendampingan secara telah berjalan dengan baik walaupun tata caranya harus berubah menjadi daring karena kendala kondisi pandemi saat ini. Antusias peserta dalam kegiatan yang dilakukan dapat diamati melalui proses diskusi dan keseriusan peserta dalam mengikuti pelatihan dan pendampingan. Kesibukan tidak menyurutkan keinginan mereka menambah ilmu. Walaupun para bidan saat ini diharuskan untuk fokus menjadi garda terdepan pada pelayanan di Puskesmas masing-masing, peserta masih mau ikut belajar mengenai pengetahuan dan keterampilannya di bidang teknologi keuangan. Hal ini dilakukan agar mampu melakukan pencatatatn transaksi keuangan dengan memanfaatkan teknologi informasi digital yang lebih praktis dan sesuai SAK EMKM.

\section{Saran}

Pelaksanaan pengabdian pada masyarakat ini agar ditindaklanjuti dengan kegiatan serupa di tahun-tahun yang akan datang dengan memperluas kajian materi dan pengembangan program tentang rekam medis yang terintegrasi dengan keuangan usaha Praktek Mandiri Bidan. Hal ini mengingat penting Program aplikasi rekam medis dan keuangan praktek mandiri bidan, sesuai yang diungkapkan oleh para Bidan di Kecamatan Sukasada. Selain itu juga diharapkan kegiatan sejenis bisa diterapkan bukan hanya di wilayah Sukasada, namun juga di wilayah lainnya.

\section{UCAPAN TERIMA KASIH}

Ucapan terima kasih kami sampaikan kepada Kepala LPPM Universitas Pendidikan Ganesha beserta staf yang telah memberikan tim kami pendanaan untuk melaksanakan pengabdian kepada masyarakat pada tahun 2020 ini. Ucapan terima kasih kepada Kepala IBI Cabang Buleleng beserta staff atas arahan dan izinnya dalam kegiatan ini. Para Ibu-ibu Bidan di Kecamatan Sukasada yang telah meluangkan waktunya di masa-masa pandemi ini untuk mengikuti kegiatan dengan antusias dari awal hingga akhir, kami ucapkan terima kasih sebesar-besarnya. Serta segala pihak yang belum bisa kami sebutkan satu per satu, terima kasih telah membantu jalannya kegiatan pengabdian kepada masyarakat ini. 


\section{DAFTAR PUSTAKA}

[1]. Ikatan Bidan Indonesia. 2015. Bidan Delima Pelayanan Berkualitas. https://ibi.or.id/id/arti cle_view/a20150115001/bidan-delima.html Akses 20 Juli 2020

[2]. Ningtyas, Mega Noerman. 2019. Literasi Keuangan Pada Generasi Milenial. Jurnal Ilmiah Bisnis dan Ekonomi Asia. Vol 13 No. 1 Hal 20-27

[3]. Herawati, dkk. (2015). Pelatihan Financial Planning Bagi Remaja di Kota Singaraja.
Laporan Akhir Program P2M Penerapan IPTEKS UNDIKSHA.

[4]. Andreastuti, Linda. (2017). Sistem Informasi Klinik Bersalin Bidan Wahyu Jatiningsih. Klaten. Skripsi. Universitas Widya Dharma

[5]. Jaya, Ahmad., Rodianto, Akbar (2019). Sistem Informasi Pencatatan Dan Laporan Pada Praktek Mandiri Bidan (PMB) "Fitri Alatif" Berbasis Dekstop. Journal Tambora; Vol 3. No. 3. 